\title{
The Renin-Angiotensin-Aldosterone System in the Newborn Lamb: Response to Furosemide
}

\author{
SHARON R. SIIEGILL':2) AND DIELBI:RT A. FISIILER \\ Departments of Pediatrics and Me'dicine, UCLA-Harbor Goneral Hospital, Torrance. California. USA
}

\begin{abstract}
Summary
Nine newborn lambs between 24 and $48 \mathrm{hr}$ of age were studied before and after infusion of furosemide $(2 \mathrm{mg} / \mathrm{kg})$ over 1-2 min. Plasma renin activity (PRA) increased within $8 \mathrm{~min}$ after furosemide from a baseline value of $12.6 \pm 3.5 \mathrm{ng} / \mathrm{ml} / \mathrm{hr}$ (mean and SEMI) to a level of $24.1 \pm 8.6 \mathrm{ng} / \mathrm{ml} / \mathrm{hr}(P<0.05)$, and peaked 20 mins after the furosemide infusion at a level of $33.1 \pm 8.0 \mathrm{ng} / \mathrm{ml} / \mathrm{hr}$. Plasma aldosterone concentration increased from a bascline of $12.2 \pm 3.1$ to $22.8 \pm 9.1 \mathrm{ng} / \mathrm{dl} 35 \mathrm{~min}$ after the furosemide infusion. $P<0.05$. There were no changes in plasma sodium or blood hematocrit and minimal changes in blood pressure and plasma protein concentrations during the first $35 \mathrm{~min}$ after the furosemide infusion. The results indicate that the renin-angiotensin-aldosterone system responds promptly to furosemide stimulation despite initially high PRA and aldosterone levels.
\end{abstract}

\section{Speculation}

The renin-angiotensin-aldosterone system responds promptly to stimulation with furosemide in the newborn lamb. despite initially high PRA and aldosterone concentrations. The high renin and aldosterone concentrations characteristic of the newborn could be due to a relative end organ insensitivity to aldosterone or to a renal glomerulotubular immaturity leading to salt wasting.

In the adult human. the renin-angiotensin-aldosterone system is important in the maintenance of blood pressure. blood volume. and sodium homeostasis. The role of the system in the fetus and newborn remains unclear. It is known that PRA (9) and plasma aldesterone levels $(1.15)$ are high during the neonatal period. The purpose of this study is to determine in the newborn lamb whether the system can respond to stimulation.

\section{MATERIALS AND METHODS}

Nine newborn lambs were studied between 24 and $72 \mathrm{hr}$ of age. After a 3() min control period. furosemide $(2 \mathrm{mg} / \mathrm{kg})$ was infused over 1-2 min. Blood samples for PRA. plasma aldosterone. plasma sodium (Na). hematocrit and plasma protein measurements were drawn 10 min before and 8.20 .35 .65 . and 12.5 min after the furosemide infusion. Urine volume and Na were measured $30 \mathrm{~min}$ before and at 2,30, and 120 $\mathrm{min}$ after the infusion in the five female lambs. Four male lambs were not catheterized.

PRA $(6,13)$ and aldosterone $(8)$ were measured by radioimmunoassay. Sodium was measured by flame photometry and plasma proteins by the biuret method (7). Blood pressure was measured with a water manometer (11) attached to an $8 F$ catheter inserted into the carotid artery. All statistics were done by paired $t$-test.

\section{RESULTS}

Baseline PRA concentrations in the newborn lamb were 12.6 $\pm 3.5 \mathrm{ng} / \mathrm{ml} / \mathrm{hr}$ (mean and SEM1) compared to a mean value of $4.2 \pm 0.78 \mathrm{ng} / \mathrm{ml} / \mathrm{hr}$ in the nonpregnant ewe $(P<0.05)$. Plasmal aldosterone levels were $12.2 \pm 3.1 \mathrm{ng} / \mathrm{dl}$ in the newborn lamb and $5.6 \pm 0.85 \mathrm{ng} / \mathrm{dl}$ in the ewe $(P<0.05 ;$ Table 1$)$.

Plasma renin activity increased within 8 min after the furosemide infusion (Figure 1) from the $12.6 \mathrm{ng} / \mathrm{ml} / \mathrm{hr}$ baseline value to a level of $24.1 \pm 8.6 \mathrm{ng} / \mathrm{ml} / \mathrm{hr}(P<0.05)$. The mean value peaked 20 min after the furosemide infusion at a level of $33.1 \pm 8.0 \mathrm{ng} /$ $\mathrm{ml} / \mathrm{hr}, P<0.01)$ and remained elevated throughout the 120 -min study period.

The mean plasma aldosterone concentration increased from the baseline of $12.2 \pm 3.1$ to $22.8 \pm 9.1 \mathrm{ng} / \mathrm{dl} 3.5 \mathrm{~min}$ after the furosemide infusion $(P<0 .(15$, Fig. 2). This level persisted for $6.5 \mathrm{~min}$ postinfusion, falling to $14.2 \pm 3.9 \mathrm{ng} / \mathrm{dl} 2 \mathrm{hr}$ after the infusion.

Blood pressure (Fig. 3) remained stable during the first $20 \mathrm{~min}$ after the furosemide infusion, dropped a mean of $3 \mathrm{~mm}$ Hg at $20 \mathrm{~min}(P<0.05)$ and to $4 \mathrm{~mm} \mathrm{Hg}$ by $35 \mathrm{~min}$ postinfusion. There were no changes in hematocrit or plasma sodium concentration during the first $30 \mathrm{~min}$ after the furosemide infusion.

There was a significant increase in plasma protein concentration (Fig. 4) 20 min after furosemide, from a base of $5.3 \pm 0.46$ $\mathrm{g} /$ dl to $5.8 \pm 0.53 \mathrm{~g} / \mathrm{dl}(P<0.01)$; values remained stable through $60 \mathrm{~min}$ but increased further at $120 \mathrm{~min}$.

The mean sodium concentration in the control urine samples in the five female animals (Table 2) increased from $7.3 \mathrm{mEq} /$ liter 30 min before furosemide to a mean of $104 \mathrm{mE}$ (y/liter at 2 min and to $120 \mathrm{mEq} /$ liter $30 \mathrm{~min}$ after the infusion. There was no change in urine potassium concentration. Urine volume increased from a mean of $1.5 \pm 0.81$ (mean and SEN1) $\mathrm{ml} / \mathrm{kg} \cdot 30$ min to $18 \pm 2.3 \mathrm{ml} / \mathrm{kg} \cdot 30 \mathrm{~min}$ after the infusion $(P<0.01)$. Sodium excretion increased from $0.02 \mathrm{mEg} / \mathrm{kg} 30 \mathrm{~min}$ in the control urine samples to $2.1 \mathrm{mEq} / \mathrm{kg} 30 \mathrm{~min}$ after the furosemide infusion $(P<0.01)$.

\section{DISCUSSION}

The newborn lamb has elevated PRA and aldosterone concentrations (Table 1) similar to the elevalted values reported in human infants $(1,9,15)$, and significantly higher than levels in the nonpregnant ewe. In response to stimulation with furosemide the mean PRA doubled within 8 min (Fig. 1) and increased about 300\% by 20 min (Fig. 1). Mean plasma aldosterone levels doubled within $35 \mathrm{~min}$ after furosemide (Fig. 2). Individual values peaked between 35 and 6.5 min. These results indicate that the renin-angiotensin-aldosterone system responds promptly to stimulation despite the initially high renin and aldosterone concentrations.

There was a rapid sodium diuresis in response to the furosemide infusion. A sodium loss of $2 \mathrm{mEq} / \mathrm{kg}$ and water loss of $18 \mathrm{ml} /$ $\mathrm{kg}$ occurred during the first $30 \mathrm{~min}$. Previous studies have shown that the maintenance of sodium and water balance by continuous 
Table 1. Baseline plasma renin activity (PRA) and aldosterone concentrations in lambs and nonpregnant ewes ${ }^{1}$

\begin{tabular}{ccc}
\hline Animals & PRA, $\mu \mathrm{g} / \mathrm{ml} / \mathrm{hr}$ & Aldosterone, $\mathrm{ng} / \mathrm{dl}$ \\
\hline Newborn lambs, $n=9$ & $12.57^{2}$ & $12.17^{2}$ \\
& $(3.51)$ & $(3.0)$ \\
Adult ewes, $n=9$ & 4.16 & 5.59 \\
& $(0.78)$ & $(0.85)$ \\
\hline
\end{tabular}

1 Values are means (SEM)

${ }^{2} P<0.05$

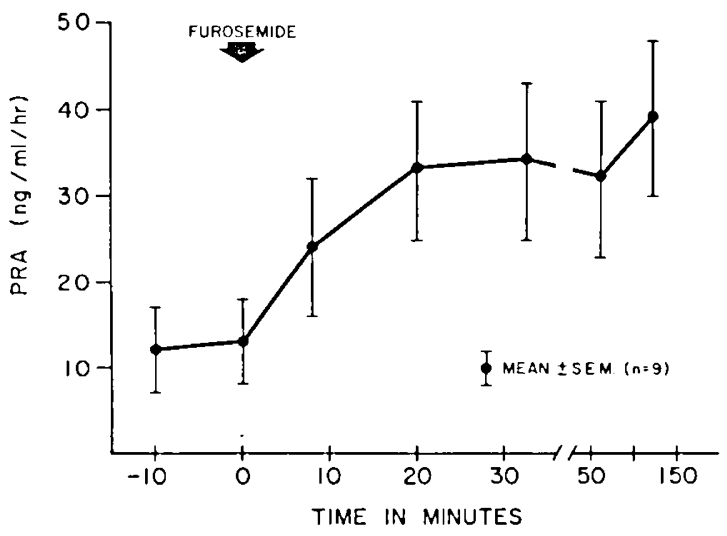

Fig. 1. Plasma renin activity $(P R A)$ response to furosemide in the newborn lamb. Furosemide, $2 \mathrm{mg} / \mathrm{kg}$, was infused intravenously over 1 2 min after two baseline PRA samples. PRA concentration increased at 8 min postinfusion $(P<0.05)$ and peaked at $20 \mathrm{~min}(P<0.01)$.

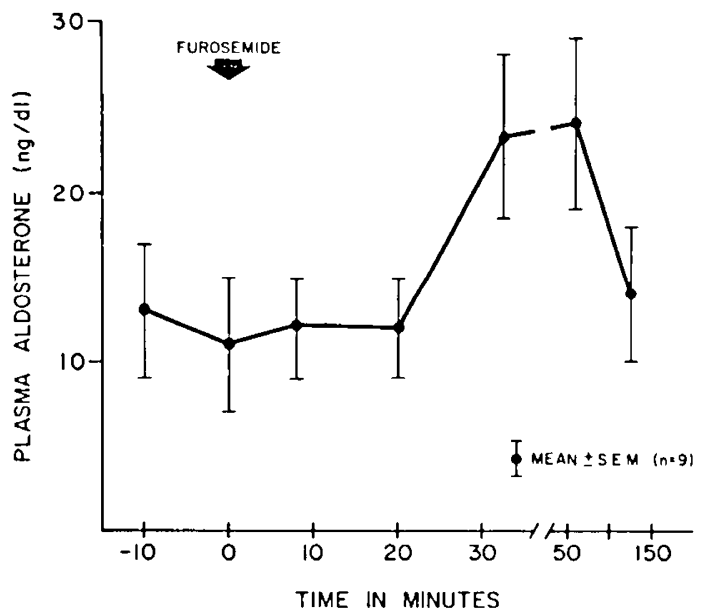

Fig. 2. Aldosterone response to furosemide in the newborn lamb. Furosemide, $2 \mathrm{mg} / \mathrm{kg}$. was infused intravenously over 1-2 $\mathrm{min}$ after two baseline PRA samples. Plasma aldosterone increased 35 min postinfusion $(P<0.05)$.

replacement of urinary losses with isotonic saline in dogs (17) or by shunting of urine into the femoral vein in rabbits (12) will not alter the furosemide-induced renin secretion, despite the constancy of blood pressure, plasma sodium concentration, and plasma volume. In the present study the renin response occurred within $8 \mathrm{~min}$, before alterations in blood pressure or plasma protein concentrations were detected, and without changes in hematocrit or plasma sodium concentration. The early PRA response might have been mediated by alterations in intrarenal hemodynamics, by increase in intratubular sodium in the region of the macula densa, or by direct inhibition of macula densa sodium transport. It has been shown that furosemide in low doses does not significantly alter glomerular filtration rate (17) or renal plasma flow. In high doses $(2.5 \mathrm{mg} / \mathrm{kg})$ renal plasma flow increases. The drug increases blood flow to the pars radiata of the kidney cortex and decreases flow to the juxtaglomerular cortex and medulla (2). Since most renal renin resides in the outer cortex, these data suggest that altered renal hemodynanics may not evoke the early renin release. Vander and Miller (18), and White (19) showed that increasing the tubular sodium load resulted in reduction of the secretion of renin induced by clamping the renal artery. A direct inhibitory effect on macula densa sodium transport thus seems more likely. The present data do not clarify the mechanism further.

The reason for the high PRA and plasma aldosterone levels in the newborn also remains obscure. They might be due to the stress or metabolic changes associated with parturition, to high baseline fetal and newborn renin and aldosterone secretion rates, to decreased metabolic clearances of the hormones, to

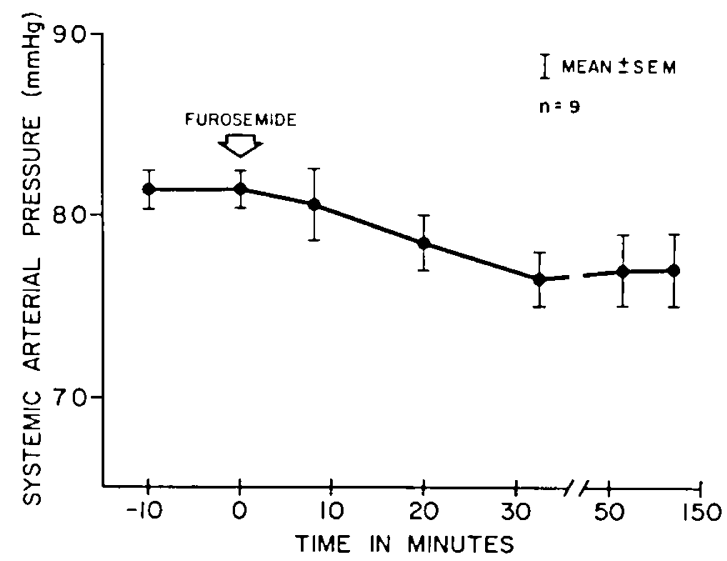

Fig. 3. Blood pressure before and after furosemide in the newborn lamb. Blood pressure dropped a mean of $3 \mathrm{~mm} \mathrm{Hg}$ at $20 \min (P<0.05)$ and $4 \mathrm{~mm} \mathrm{Hg}$ by $35 \mathrm{~min}$ postfurosemide $(2 \mathrm{mg} / \mathrm{kg}$ ) infusion.

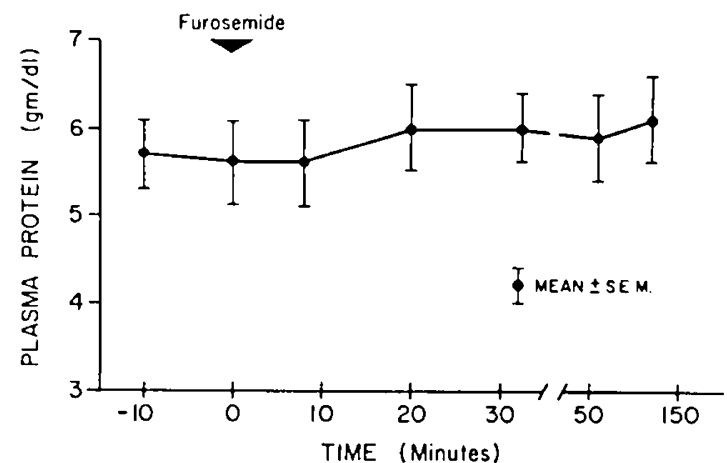

Fig. 4. Plasma protein concentrations before and after furosemide in the newborn lamb. The furosemide infusion. $2 \mathrm{mg} / \mathrm{kg}$. Was begun at zero time. The plasma protein concentration was significantly increased above baseline $(P<0.01) 20$ min after the infusion was begun.

Table 2. Urine sodium and volume changes in response to furosemide in newborn lambs ${ }^{1}$

\begin{tabular}{ccc}
\hline Urine & $\begin{array}{c}\text { During 30 min } \\
\text { before furosem- } \\
\text { ide }\end{array}$ & $\begin{array}{c}\text { During 30 min } \\
\text { after furosemide }\end{array}$ \\
\hline Sodium (mEq/liter $/ 30 \mathrm{~min})$ & 7.3 & 120 \\
Sodium $(\mathrm{mEq} / \mathrm{kg} / 30 \mathrm{~min})$ & $(0.94)$ & $(0.47)$ \\
& 0.017 & 2.12 \\
Volume $(\mathrm{ml} / \mathrm{kg} / 30 \mathrm{~min})$ & $(0.004)$ & $(0.24)$ \\
& 1.5 & 18 \\
& $(0.41)$ & $(2.3)$ \\
\hline
\end{tabular}

1 Values are means SEM; $n=5$. 
relative end organ insensitivity to aldosterone, or to increased renal salt loss due to glomerulotubular immaturity. The fact that PRA (9) and plasma aldosterone concentration (10) remain high during the first month of life suggests that events related to parturition are not involved. Kowarski et al. (10) have shown that metabolic clearance and production rates of aldosterone are higher on a body surface area basis in infants than in adults. The present results show that the renin-angiotension-atlosterone system is appropriately linked to a juxtaglomerular cell stimulus. Finally, carlier data indicate that plasma aldosterone levels in the newborn are related to urine sodium excretion (15). Thus, relative end organ insenstivity to aldosterone and/or renal glomerulotubular immaturity leading to salt wasting would seem to be possible explanations for the altered renin and aldosterone metabolism in the newborn.

Several lines of evidence would support this view. Greenberg (5) observed that normal newborn infants failed to show an increase in renal tubular sodium reabsorption in response to exogenous aldosterone; the newborn continues to excrete sodium in the face of a salt-free intake (4); the preterm infant excretes excessive sodium (16) and can develop hyponatremia within a few weeks (14); the rate of sodium transport in the proximal tubule of the infant rat is suppressed (3). Further study is necessary to clarify the defect(s).

\section{CONCLUSION}

Furosemide stimulated the renin-angiotensin system and promptly evoked aldosterone secretion in the newborn lamb. There were no changes in plasma sodium or hematocrit and minimal changes in blood pressure and plasma protein during the first $35 \mathrm{~min}$ following the furosemide infusion. This data, plus other studies in the literature, suggest that the early PRA response might have been mediated by a direct inhibitory effect on macula densa sodium transport. The present study also confirmed high baseline PRA and aldosterone concentrations in the newborn period. The mechanism for these alterations remains obscure.

\section{RIFERENCES AND NOTES}

1. Beitins, 1. Z., Bayard, F., Levitsky, L., Ances, I. G., Kowarski, A., and Migeon, C. J.: Plasma aldosterone concentration at delivery and during the newborn neriod. J. Clin. Invest.. 51: 386 (1972).

2. Birtch, A. (j., Zakheim, R. M., Jones, 1. B., and Barger, A. C.: Redistribution of renal blood flow produced by furesemide and ethacrynic acid. Circ.
Res., 21:869) (1967).

3. Capels, K., Dlouka, H., Fernandez, J., and Popp, M.: Regulation of proximal tubule reatosrption in early postnatal period of infant rats. Proceedings of the XXIV International Congress of Physiolugical Science, Volume VII, p. 72, Washington, D.C., 1968 .

4. Check, D. B. Maddison, T. G Malinek, M., and Coldbeck, J. H.: Further observation on the corrected bromide space of the neonate and investigation of water and electrolyte status in infants born to diabetic mothers. Pediatrics, 28: 861 (1961).

5. Greenberg. A.: Renal tubular response to aldosterone in normal infants and children with adrenal disorders. J. Clin. Endocrinol. Mctab., 27: 1197 $(1967)$.

6. Haber, E., Koerner, T., Page, L. B., Kliman, B., and Purnode, A.: Application of a radioimmunoassay for angiotensin I in normal human subjects. J. Clin. Endocrinol. Netab., 29: $1349(1969)$

7. Henry, R. J., Sobel, C., and Berkman, S.: Protein determination by the biuret reaction. Anal. Chem., 29: 1491 (1957).

8. Ito, T., Woo, J., Hening, R., and Horton, R.: A radioimmunoassaly for aldosteronc in buman peripheral plasma including a comparison of alternate techniques. J. Clin. Findecrinol. Metah.. 34: 106 (1972).

9. Kotchen, T. A., Strickland, A. L., Rice, T. W., and Walters, D. R.: A study of the renin-angiotensin system in newborn infants. J. Pediat., so: 938 (1972).

10. Kowarski, A., Katz, H., and Migeon. C. J.: Plasma aldosterone concentration in normal subjects from infancy to adulthood. J. Clin. Indecrinol. Mtetab., 38: $489(1974)$.

11. Leike, R. D., Williams, P. R., and Oh, W.: Validity of neonatal blood pressure obtained by the manometric method. Pediatrics, 52: 293 (1973).

12. Meyer, P., Menard, J., Papanicolaou, N., Alexandre. J. M., Devaux. C., and Milliez, P.: Mechaniom of renin release following furosemide diuresis in rabbits. Amer. J. Physiol., 215: 908 (1968).

13. Radioimmunolegy Mamual, 3rd Fd., p. 76 (Nichols Institute of Endocrinology, San Pedro, Calif., 1976).

14. Roy, R. N., Chance, (;. W., Radde, I. C., Hill, D. E., Willis, D. M., and Sheepers, J.: Late hyponatremia in very low birthweight infants $(<1.3$ hilograms). Pediat. Res., 10: 526 (1976)

15. Siegel, S. R., Vibher, D. A.., and Oh, W.: Serum aldosterone concentrations related to sodium balance in the newborn infant. Pediatrics, $53: 410(1974)$.

16. Sicgel, S. R., and Oh, W.: Renal function as a marker of human fetal maturation. Acta Pediat. Scand., 0.5: 481 (1976).

17. Vander, A.J.. and Carlson, J.: Mechanism of the effects of furosemide on renin secretion in anesthetized logs. Circ. Res., 25: 145 (1969).

18. Vander, A. J., and Mliller, R.: Control of renin secretion in the anesthetized dog. Amer. J. Physiol., 207: 537 (1964)

19. White, R. N.: Control of renin secretion in the dog. Circulation, 32 (Suppl. 2): $219(1965)$.

20. The authors wish to thank Dr. C. Dennis Ashby and Robert MacPhec of Nichols Institute for their help with the radiommunosasays. We thanh Ilocehst-Roussel Pharmaceuticals for providing the Lasix.

21. This research was supported by Grants 5-S(1-RR05551-14 and HI)-06335 from the National lnstitutes of Child Health and Human Development. National Institutes of Ilealth, Bethesda, Md.

22. Requests for reprints should be addressed to: S. R. Siegel. M.D., Harbor General Ilospital, 1000) W'. Carson St., Bidg. A-17, Torrance, Calif. 90509 (USA).

23. Received for publication October 26, 1976

24. Accepted for publication December 21, 1976. 